\title{
Palm Oil Mill Effluent (POME) utilization for bio-hydrogen production targeting for biofuel : optimization and scale up
}

\author{
Joni Prasetyo ${ }^{1}$, S.D.Sumbogo Murti ${ }^{1}$, Semuel Pati Senda ${ }^{1}$, Andi Djalal Latief ${ }^{2}$, R. Dwi Husodo Prasetyo ${ }^{1}$, \\ Zulaicha Dwi Hastuti ${ }^{1}$, Fusia Mirda Yanti $^{1}$, Firdaus Juanda ${ }^{3}$, Edwin Permana ${ }^{3}$ and Lince Muis ${ }^{3}$ \\ ${ }^{I}$ Center for Energy Resources Technology and Chemical Industry, Agency for the Assessment and Application of Technology \\ ${ }^{2}$ Center for Information and Communication Technology, The Agency of Assessment and Application of Technology \\ ${ }^{3}$ Department of Chemistry, Faculty of Science and Technology, Jambi University
}

\begin{abstract}
Indonesia is the largest palm plantation that reaches 32 million tonnes palm oil production per year with 84 million tones Palm Oil Mill Effluent (POME) as liquid waste. POME contains many organic substances. The quality of POME for its utilization is generally measured in COD which has range $30000-100.000$ ppm. Microbial convertion for biogas especially for bio- $\mathrm{H}_{2}$ enrichment, the active sludge was pretreated physically to suppress methanogenesis microbes. $\mathrm{H}_{2}$ Biogas production was conducted at $\mathrm{pH}$ 5-6. Additional $10 \%$ phosphate buffer was done in the beginning only. The production of $\mathrm{H}_{2}$ biogas was influenced by hydrostatic pressure in closed batch system. Inoculumsmedium ratio also influenced the $\mathrm{H}_{2}$ biogas productivity, reached $0.7 \mathrm{ml} / \mathrm{ml} \mathrm{POME}$ with more than $50 \% \mathrm{H}_{2}$. Scaling up anaerobic in $2.5 \mathrm{~L}$ working volume bioreactor, $\mathrm{H}_{2}$ biogas productivity reached $0.86 \mathrm{ml} / \mathrm{ml}$ POME by $10 \%$ inoculums because of no hydrostatic pressure. In bio-reactor, $\mathrm{H}_{2}-\mathrm{CO}_{2}$ in $\mathrm{H}_{2}$ biogas was affected by the amount of active sludge. In the beginning of $\mathrm{H}_{2}$ biogas, $\mathrm{H}_{2}$ reached $80 \%$. However, at subsequence process, fed batch, with retention time 2.5 day and 3 days $\mathrm{H}_{2}$ biogas production, the active sludge was accumulated and caused the decreasing $\mathrm{H}_{2}$, finally only $46 \%$ at the $3^{\text {rd }}$ day. The consortium tended to produce more $\mathrm{CO}_{2}$ as the result of primary metabolite rather than $\mathrm{H}_{2}$. Raising inoculums to level $15 \%$ improved productivity only in the beginning but $\mathrm{H}_{2}$ content was getting less, only $59 \%$. Additional feeding would cause more accumulation sludge and more decreasing $\mathrm{H}_{2}$ content to $31 \%$ on the $3^{\text {rd }}$ day. Thus, the ratio of active sludge and substrate availability must be controlled to gain optimum $\mathrm{H}_{2}$. Limited substrate will cause the direction of bio-conversion more in $\mathrm{CO}_{2}$ rather than $\mathrm{H}_{2}$.
\end{abstract}

\section{Introduction}

Final energy in term of the energy utilized by endenergy users is mostly consumed in the industrial sector, followed by household and transportation. Especially in transportation sector, the average consumption always increases annually up to $6.46 \%$ [1]. This increasing in energy demand is related to in the number of motor vehicles in Indonesia that reached 19 million by 2000 and 121 million by 2015 , average annual increasing was $7.8 \%$ [2]. This condition could trigger instability of energy sovereign in Indonesia whereas the consumption reached 300 million barrels in 2014 while the production is only 288 barrels [3]. On the other hand, related to the depletion of fossil fuel sources, the government is aiming to increase the target of renewable energy utilization by $0.5 \%$ in 2014 and continue to be increased to $9.5 \%$ by $2030[4,5]$

Indonesia is well known as the largest palm oil producer in the world with 22.2 million ha plantation area and crude palm oil (CPO) production reached 31 million tons per year $[4,5]$. However, this palm oil production has led to the accumulation of a huge amount palm oil mill effluent (POME) disposed as liquid wastes. The estimation POME was 2.5 tons POME / ton CPO [6]. POME contains extremely high organic compounds and generally measured by chemical oxygen demand (COD) and biological oxygen demand (BOD) which were about 30,800 and 7,800 ppm, respectively $[7,8]$. In addition, even the COD and BOD can reach 96,300 and $53,200 \mathrm{ppm}$ at some palm oil companies [9]. Due to the extremely high content of 
organic compounds, POME can be utilized as carbon source for microbes. Therefore, POME can be used as raw material for Hydrogen production, an energy carrier [10].

Hydrogen is high potential as energy carrier. The energy content can reach up to 2.75 times higher than light hydrocarbon, $122 \mathrm{~kJ} / \mathrm{g}$ [11]. It can be treated by biological method that technically offers some advantages like more easily in the stage of workmanship, environmentally friendly, low energy consumption and economically more feasible [10]. To enrich hydrogen production from POME, the activated sludge was developed from cow manure. Originally, the activated sludge will contain some microbes like Caldoanaerobacter subterraneus, Caloramator fervidus, and Clostridium thermocellum for thermophilic [12-14]. The others are like Methanospirillum hungatei and Methanosarcinaciciliae, methanogenesis microbes and mesophilic $[15,16]$. The method undertaken to eliminate methane production is suppressing methanogenic microbes with heating treatment so that methanogenesis microbes was not survive [17]. Previous researchers have yielded $17.1 \mathrm{~mL} \mathrm{H}_{2} / \mathrm{g}$ COD without any treatment [18]. The other researchers succeeded in increasing the productivity through the ozone treatment for POME achieved $70.1 \mathrm{~mL} \mathrm{H}_{2} / \mathrm{g}$ COD [19].

This study assesses the production of hydrogen from POME over Up-flow Anaerobic Sludge Reactor (UASR) at bench scale. Active sludge that developed from cow manure in fact produce hydrogen with very less $\mathrm{H}_{2} \mathrm{~S}$ [21]. UASR offers more efficiency system for the conversion to biogas, particularly hydrogen. The hypothesis is by streaming up POME, the carbon source, will make the conversion of POME rendering according the denser microbes at the bottom of the reactor. At upper layer, the denser of microbe was lesser with carbon concentration of POME also lesser.

\section{Material and Methods}

\subsection{Materials}

\subsubsection{POME}

POME for this study was provided by Kertajaya Ltd, a state-owned palm oil company (PTPN VIII), located in Malimping, Banten province. The head office of PTPN VIII is in Bandung, West Java.

Table 1 Characteristics of fresh POME.

\begin{tabular}{ll}
\hline Characteristic & $\begin{array}{l}\text { Concentration } \\
(\mathrm{ppm})\end{array}$ \\
\hline COD & 32,800 \\
BOD & 7,800 \\
Total suspended solid (TSS) & 9,800 \\
Oil and grease & 1,800 \\
$\mathrm{pH}$ & $4.0-4.5$ \\
\hline
\end{tabular}

\subsubsection{Active sludge}

Active sludge containing microbial consortium that was developed from POME was obtained from Adolina Ltd., Medan, North Sumatera. The active sludge was mixed with cow manure to enrich hydrogen concentration in biogas. Initial gas production testing conducted for POME by PTPN III and applicable also for the POME from PTPN VIII with yielded almost similar results.

\subsubsection{Buffer}

The phosphate buffer that was used only at the beginning of anaerobic fermentation. The buffer was provided by Merck EMD Millipore Corporation, a German firm. $\mathrm{KH}_{2} \mathrm{PO}_{4}$ and $\mathrm{K}_{2} \mathrm{HPO}_{4}$ were mixed in varying ratios to get $\mathrm{pH} 5.0,5.5,6.0,6.5$ and 7.0.

\subsection{Methods}

Suppressing methanogenesis: Active sludge, through indirect heating, was heated to $95^{\circ} \mathrm{C}$ for 1.5 hours in order to suppress methanogenesis microbes.

\subsubsection{Batch experiment.}

Biogas production for hydrogen was done in $100 \mathrm{~mL}$ bottles closed. The working volume was arranged between 50 and $80 \mathrm{~mL}$. With bottles closed tightly, the hydrogen biogas produced was trapped and the biogas produced was measured every two days. The active sludge was collected and used at bioreactor $2.5 \mathrm{~L}$. Hydrogen biogas production both at bottle and bioreactor scales used buffer only at starting fermentation for $10 \%$. The amount of active sludge in bioreactor was varied at 5, 10 and $15 \%$.

\subsubsection{Fed Batch experiment.}

Biogas production was scaled up in a semi-continuous system with total incubation time of of five days. The fermentor used has a volume of $2.5 \mathrm{~L}$ and a working volume of about $2 \mathrm{~L}$. This system is equipped with a separator to separate POME liquid waste from the resulting gas. The feeding of POME was conducted using a persitaltic pump at minimum speed. The fermentor system also has features lika $\mathrm{pH}$ monitoring tool. Increased hydrogen production was also done with the semi continuous process by using Up Stream An aerobic Sludge (UASR) with 2 L working volume, a bioreactor.

\subsection{Analysis}

\subsection{1. $C O D$.}

COD was analyzed using the Lovibond MD 100 COD kit with $0-15,000 \mathrm{ppm}$ COD/CSB vials containing potassium dichromate, $\mathrm{HgSO}_{4}$ and $61 \%$ sulfuric acid. Generally, fresh POME has a range of between 15,000 
and 100,000 ppm [21]. Therefore, the sample should be dilluted using aquadest in 2-8 times, according to COD prediction.

\subsubsection{Gas chromatograph}

Gas chromatograph thermal conductivity detector (GC shimadzu-TCD 8A) and Shimadzu 2014 were used to analyze the hydrogen, carbon dioxide $\left(\mathrm{CO}_{2}\right)$ and methane $\left(\mathrm{CH}_{4}\right)$. Injection temperature, cooling temperature and final temperature were arranged automatically for 100,50 and $50^{\circ} \mathrm{C}$, respectively. Gas in the sampling bag was inserted by pushing the sampling bag smoothly for 30 seconds.

\subsubsection{Water displacement}

Water displacement was used to measure the total biogas produced. The biogas that had passed through this water displacement was collected in a sample bag and analyzed its composition using GC Simadzu-TCD $8 \mathrm{~A}$.

\section{Result and Discussion}

Recheck biogas production using POME and cow manure showed the consistency in which the treated active sludge produced no methane. Moreover, the $\mathrm{H}_{2} \mathrm{~S}$ was also not detected [20]. Therefore, in this method, utilization of POME, only produced $\mathrm{CO}_{2}$ and $\mathrm{H}_{2}$. The second recheck was conversion of POME to hydrogen biogas was by analyzing the reduction of COD and BOD. The COD and BOD of POME were compared before and after the production of hydrogen biogas. Confirmation of previous experiment, COD dropped mostly by $30 \%$ and almost all the BOD degraded by one-day retention time. The yield of hydrogen biogas reached $0.7 \mathrm{ml} / \mathrm{ml}$ POME at the scale of $100 \mathrm{ml}$ working volume [17].

\subsection{Hydrogen Biogas at $2.5 \mathrm{~L}$ working volume}

Hydrogen biogas production was conducted using various percentages of active sludge. The biogas production was produced from the beginning but it was measured after 24 hours. Using bioreactor was conducted in order to minimize hydrostatic pressure because hydrostatic pressure has an adversely negative influence on methanogenesis and hydrogen production as well [12]. The biogas flew through separator and water displacement. Finally, the biogas was kept at sampling bag for composition analysis. By this system, the pressure on surface POME was kept low, no hydrostatic pressure.

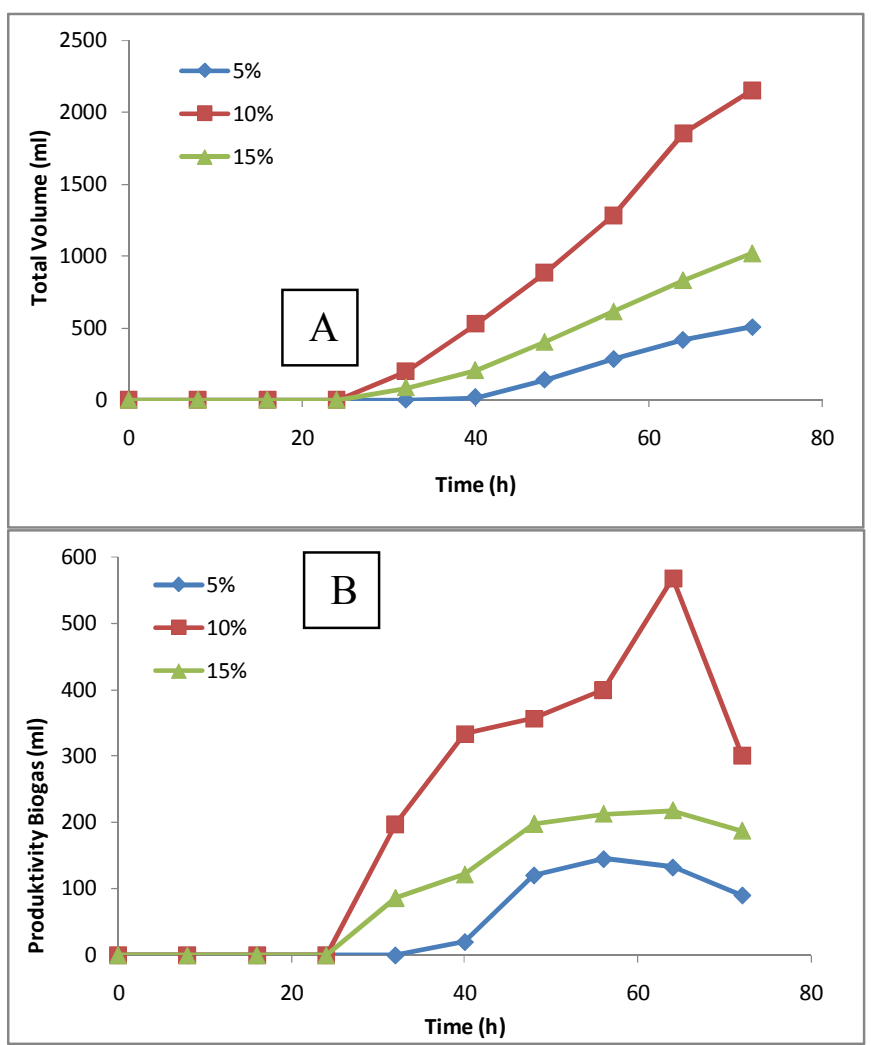

Fig. 1. Hydrogen biogas production at $2.5 \mathrm{~L}$ bioreactor (A) Total volume of hydrogen biogas, (B) Hydrogen biogas production every 8 hour.

At batch process, the biogas production decreased after a while because of not enough substrate to be consumed. In this case, the main substrate consumed by microbes was represented by BOD rather than COD. The biogas production by $5 \%$ active sludge was the slowest and this condition was acceptable. The microbes needed more time to produced the same amount hydrogen biogas. Using $15 \%$ active sludge showed very fast bubbling production at the surface POME but the amount hydrogen biogas measured was less than the biogas production using $10 \%$ active sludge at $32^{\text {nd }}$ hour. At the end batch process, the highest yield was gained using $10 \%$ active sludge reached $1.07 \mathrm{ml}$ biogas / $\mathrm{ml}$ POME, the optimum amount of active sludge.

\subsection{Fed batch Process}

POME was fed to bioreactor starting at $72^{\text {nd }}$ hour when the biogas production began decreasing. At the average additional POME for $1 \mathrm{~L} /$ day, hydrogen biogas production showed in the same pattern for all experiments: 5,10 and $15 \%$ active sludge as shown in Fig. 2. Along with the POME feeding in, it forced POME at the top layer out flowing with the hydrogen biogas through separator section. The biogas would up flow and be measured by water displacement. The biogas was collected and in total volume the biogas was analyzed its composition. The collected of biogas was accumulated daily and the yield was between 0.37 $0.45 \mathrm{~mL}$ hydrogen biogas / $\mathrm{mL}$ POME. This yield was 
much lower than the maximum yield at batch system. Lower yield after feeding in was caused by shorter retention time which was the lowest speed of peristaltic pump. The retention at batch phase was 3 days while the retention time of fed batch was 1.875 days. Therefore, it should be able produce more hydrogen biogas if the production was conducted at bigger bioreactor.

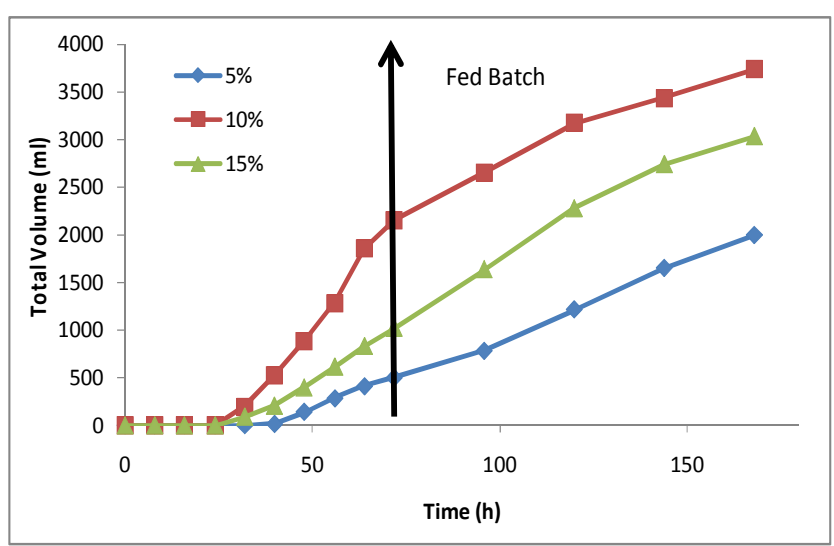

Figure 2. Hydrogen biogas production at batch and fed batch phase.

\subsection{The composition of hydrogen biogas}

All of analyzed biogas showed that methane was not detected. Therefore, the biogas produced in this POME utilization was only 2 components: hydrogen and carbon dioxide. At batch process, the hydrogen content was usually very high. However, along with the growth of microorganism in active sludge, the hydrogen slightly decreased and carbon dioxide composition slightly increased.

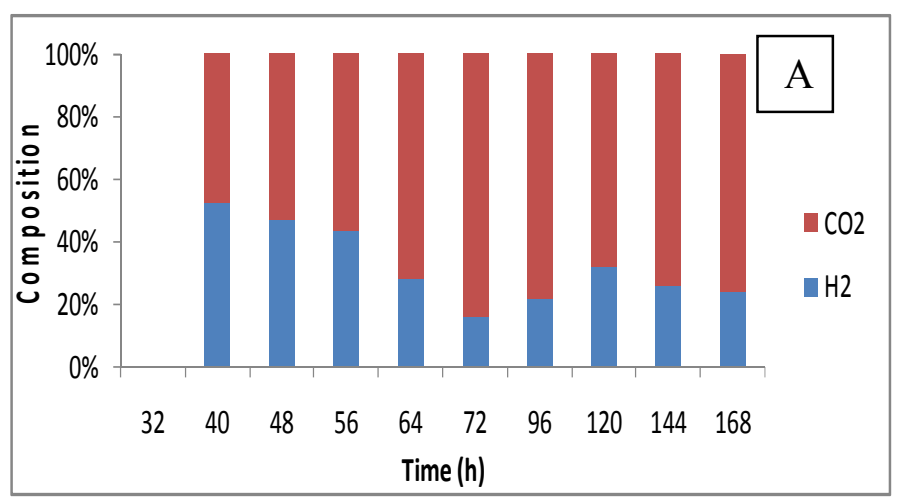

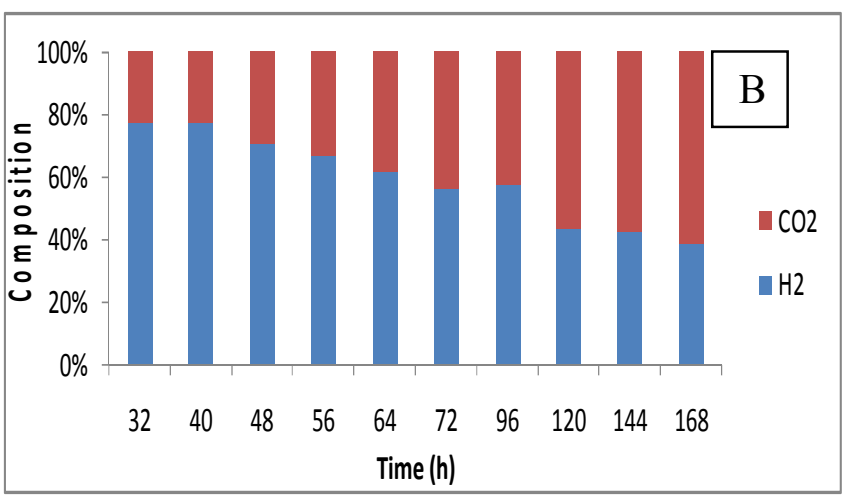

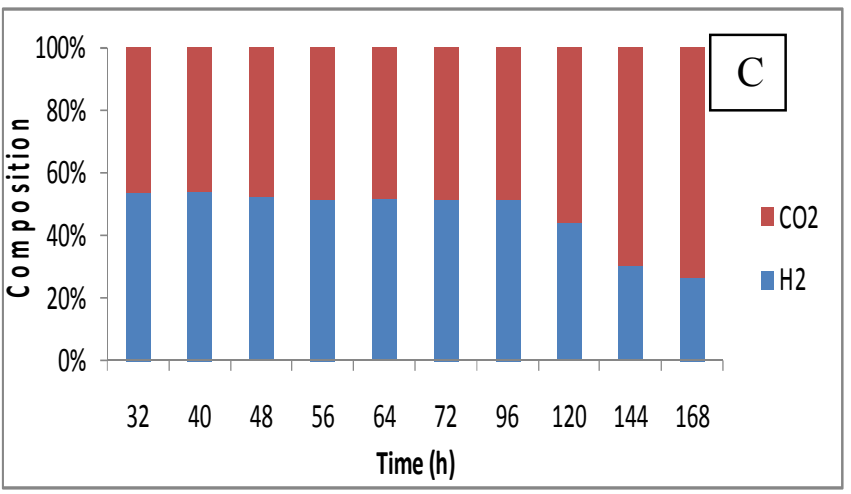

Figure 3. The composition biogas for hydrogen and carbon dioxide (A) starter 5\% (B) starter 10\% and (C) starter $15 \%$.

As shown in figure 3 , batch process up to $72^{\text {nd }}$ hour, hydrogen was still high in the beginning reached more than $50 \%$ for any experiment. However, along with fermentation time, the hydrogen composition slight decreased and conversely carbon dioxide slightly increased. The growth of microorganism will consume more substrate and from their mechanism the biogas was produced. The biogas products that tended to produce $\mathrm{CO}_{2}$ along with microbial growth and reduced substrate. This shifting biogas composition can be interpreted that carbon dioxide is the product of primary metabolite while hydrogen is the product of secondary metabolite.

At fed batch phase, additional POME caused hydrogen composition slightly increased or stable in the beginning. Unfortunately, most of sludge tended to place in bottom place. Along fermentation time, the active sludge was accumulated. Therefore, the number of microbes was also getting bigger. This amount of sludge influenced the composition of biogas significantly. The same reason to batch phase, the amount microbes would influence the biogas composition. 

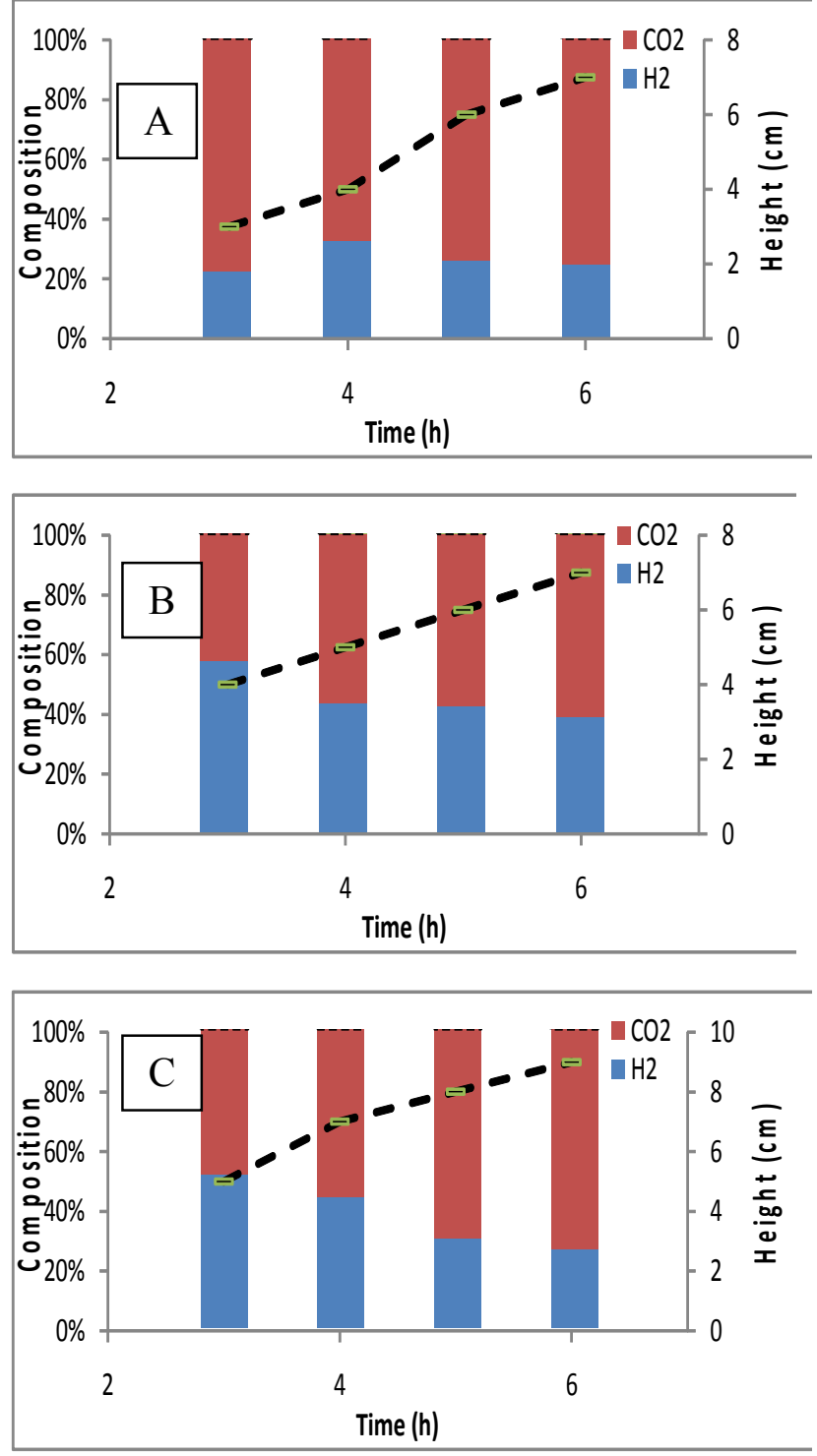

Figure 4. The composition biogas and the height (A) starter $5 \%$ (B) starter $10 \%$ and (C) starter 15\%.

The main target of POME utilization is hydrogen. Based on this data, the amount of active sludge must be control in order to produce hydrogen rather than carbon dioxide. Too much active sludge will produce more carbon dioxide so that the amount of active sludge should be reduced. On the other hand, less active will cause longer bio-conversion of POME to produce hydrogen biogas. Therefore, the amount of active sludge should be controlled in bioreactor.

\section{Conclusion}

The development of POME utilization to produce hydrogen biogas showed some parameters that affect hydrogen conversion. Firstly, hydrostatic pressure influenced the bioreactor system so that hydrostatic pressure should be minimized. To maintain minimum this affect, the biogas must be drained into storage so that no excess pressure on the POME surface in the bioreactor. Minimizing hydrostatic pressure can improve hydrogen biogas production up to $20 \%$.
Secondly, the comparison between the number of microbes and the availability of substrate will affect the resulting biogas composition. When the availability of substrate is limited, carbon dioxide will be generated as the product of primary metabolite rather than hydrogen. On the other hand, reducing the amount of active sludge will cause hydrogen production need longer retention time. Thus, the amount of active sludge should be controlled to gain the optimum hydrogen biogas.

\section{References}

1. BPPT, Outlook Energi Indonesia 2016, Jakarta: PTPSE-BPPT (2016).

2. BPS, Perkembangan Jumlah Kendaraan Bermotor Menurut Jenis. Jakarta: Badan Pusat Statistik (2014).

3. PTPSE, Outlook energi Indonesia 2011, PTPSE BPPT, Jakarta, (2011).

4. BPS, Luas Tanaman Perkebunan Menurut Propinsi dan Jenis Tanaman, Indonesia. Jakarta: Badan Pusat Statistik (2015).

5. Directorate General of Estate Crops, The Crop Estate Statistics of Indonesia: 2015-2017 Palm Oil, Secretariat of Directorate General of Estate Crops, Jakarta, (2016).

6. Ho C.C., Tan Y.K., Wang C.W., Agric. Wastes, 11, 61-74, (1984).

7. Taha M.R., Ibrahim A.H., Jour. water process eng., 1, 8-16,(2014).

8. Wong Y.S., Kadir M.O.A.B., Teng T.T., Bioresour. Technol., 100, 4969-75, (2009).

9. Singh, L., M. F. Siddiqui, A. Ahmad, M. H. A Rahim dan Z. A. Wahid, Jour. Ind.and Eng. Chem., 19. 659-664, (2013).

10. Norfadilah N., Raheem A., Harun R., Ahmadun F.R., Intern. Jour. hydrogen energy, 41, 11960-4, (2016).

11. Bockris, J. O. M., Intern. Jour. Hydrogen Energy, 27, 731-740, (2002).

12. Yokoyama, H., Moriya, H. Ohmori, M. Waki, A. Ogino and Tanaka, Y., Appl. Microbiology Biotech., 77, 213-222, (2007).

13. Girija, D., Deepa K., Xavier F., Antony I., and Shidhi, P.R., Indian Jour. of Biotech., 12, 373-378, (2013).

14. Patel B. K. C., Monk C, Littleworth H., Morgan H.W., and Daniel R.M., Intern. Jour. Systematic Bact., 123-126 (1987).

15. Sundarassu, S. P. and Benila J.M.S., Intern. Jour. Research, 4 (7): 1-10, (2017). 
16. Mladenovska, Z., Dabrowski S., and Ahring B.K., Water Sci. Tech., 48 (6), 271-278, (2003).

17. Prasetyo J., et. al., Res. J. Chem. Env., Special issues, 245-248, (2018).

18. Tanikkul, P and Pisutpaisal, N., Energy Procedia, 61, 1234-1238, (2014).

19. Nipon P., Tanikkul, P. dan Phoochinda, W., Energy Procedia. 50, 723-728, (2014).

20. McKinsey-Zicari S., Removal of hydrogen sulphyde using cow manure compost. Master Thesis. Department of Biological and Environmental Engineering, Cornel University, (2003).

21. Madaki Y.S., and Seng L., Intern. Jour. Sci., Env. and Tech., 2 (6), 1138 - 55, (2013) . 